\title{
Comparison of Oxidizing Agents for the Oxidative Coupling of Methane over State-of-the-Art Catalysts
}

\author{
K. Langfeld ${ }^{1}$, B. Frank ${ }^{2}$, V. E. Strempel ${ }^{1}$, C. Berger-Karin ${ }^{3}$, G. Weinberg ${ }^{2}$, E. V. Kondratenko ${ }^{3}$, \\ R. Schomäcker ${ }^{1, *}$
}

${ }^{1}$ Institute of Chemistry, Technical University Berlin, Straße des 17. Juni 124, 10623 Berlin, Germany

${ }^{2}$ Department of Inorganic Chemistry, Fritz Haber Institute of the Max Planck Society, Faradayweg 4-6, 14195 Berlin, Germany

${ }^{3}$ Leibniz Institute for Catalysis at the University of Rostock, Albert-Einstein-Straße 29a, 18059 Rostock, Germany

*Corresponding author: e-mail schomaeker@tu-berlin.de,

Received 19 October 2011; Received in revised form 20 December 2011; Accepted 21 December 2011; Available online 31 December 2011

\begin{abstract}
The synthesis of selected state-of-the-art catalysts providing high performances in the oxidative coupling of methane (OCM) with $\mathrm{O}_{2}$ was reproduced according to the respective methods reported in literature. A reference material with identical stochiometric composition was further synthesized by applying the cellulose templating (CT) method. This method increases the surface area and affects the phase composition and crystallite size of the catalysts as determined by $\mathrm{N}_{2}$-physisoprtion, X-ray diffraction (XRD), and scanning electron microscopy. This, however, is in most cases detrimental to the catalytic OCM performance due to enhanced global activity resulting in hot spots in the catalyst bed. Prepared catalysts were tested in the OCM under variation of temperature (973-1073 K), GHSV (3,600-100,000 $\left.\mathrm{h}^{-1}\right)$ and oxidizing agent $\left(\mathrm{O}_{2}\right.$ and $\left.\mathrm{N}_{2} \mathrm{O}\right)$. In general, conversions of $\mathrm{CH}_{4}$ when using $\mathrm{N}_{2} \mathrm{O}$ are lower than in the presence of $\mathrm{O}_{2}$, however, the selectivities to $\mathrm{C}_{2}$ products ethane and ethylene are higher even at a similar level of $\mathrm{CH}_{4}$ conversion. This confirms the presence of different oxygen species formed by activation of these oxidizing agents.
\end{abstract}

Keywords: $\mathrm{C}-\mathrm{H}$ activation, oxygen, nitrous oxide, cellulose templating, deactivation

\section{Introduction}

The use of methane as a chemical feedstock and its transformation into higher hydrocarbons has been the focus of a number of research efforts for several decades. With increasing oil prices especially the Fischer-Tropsch (FT) process via synthesis gas, which is obtained, e.g., by steam reforming of methane, actually retrieves a lot of attractiveness. However, one drawback with regard to process costs is the need for two individual reactors to consecutively produce synthesis gas and higher hydrocarbons or alcohols. Even more complex is the route to high-value olefins via methanol, which is synthesized from synthesis gas. A highly attractive one-step transformation is the oxidative coupling of methane (OCM) to $\mathrm{C}_{2}\left(\mathrm{C}_{2} \mathrm{H}_{6}\right.$ and $\left.\mathrm{C}_{2} \mathrm{H}_{4}\right)$ hydrocarbons ethane and ethylene discovered in the early 1980's
[1]. This reaction, even though extensively investigated and optimized for almost three decades, provides low $\mathrm{C}_{2}$ selectivities at high industrially relevant methane conversions due to consecutive oxidation of produced hydrocarbons to $\mathrm{CO}$ and $\mathrm{CO}_{2}$. A $\mathrm{C}_{2}$-yield of $30 \%$ is regarded as the economically feasible limit for industrial realization of the process [2].

To improve the OCM selectivity a variety of less active oxidizing agents such as $\mathrm{N}_{2} \mathrm{O}, \mathrm{CO}_{2}$, and $\mathrm{H}_{2} \mathrm{O}$ have already been tested. This is not only for environmental reasons $-\mathrm{N}_{2} \mathrm{O}$ and $\mathrm{CO}_{2}$ are important greenhouse gases and their value added chemical transformation is highly desired [3] - but the major intention is the formation of more selective surface oxygen species on the catalyst. Clearly, the formation of electrophilic peroxo-species, which would favor the combustion of adsorbed hydrocarbons during 
OCM [4,5], is less probable when using these mild oxidizing agents because $\mathrm{N}_{2} \mathrm{O}, \mathrm{CO}_{2}$, and $\mathrm{H}_{2} \mathrm{O}$, contrarily to $\mathrm{O}_{2}$, can provide only one $\mathrm{O}$ atom for the catalyst reoxidation. The reaction mechanisms proposed for OCM are quite similar for each oxidizing agent and start with generation of surface active oxygen species from the oxidizing agent (Eqs. 1-3). Depending on the oxidizing agent, $\mathrm{N}_{2}$ [6-9], $\mathrm{CO}$ [10-12], or $\mathrm{H}_{2}$ [13] are formed as the by-product in these reaction steps. The reaction of $\mathrm{O}_{2}$ (Eq. 1) is reported to pass a peroxo intermediate $[5,14]$.

$$
\begin{aligned}
& 1 / 2 \mathrm{O}_{2}+(\mathrm{)} \rightarrow(\mathrm{O}) \\
& \mathrm{N}_{2} \mathrm{O}+\left(\mathrm{)} \rightarrow(\mathrm{O})+\mathrm{N}_{2}\right. \\
& \mathrm{CO}_{2}+() \rightarrow(\mathrm{O})+\mathrm{CO} \\
& \mathrm{H}_{2} \mathrm{O}+\left(\mathrm{)} \rightarrow(\mathrm{O})+\mathrm{H}_{2}\right.
\end{aligned}
$$

The following (selective) reaction pathway is the oxygen-assisted $\mathrm{CH}_{4}$ activation to form a methyl radical and a surface $\mathrm{OH}$ group $[15,16]$. The latter recombines to form gaseous $\mathrm{H}_{2} \mathrm{O}$ and a vacancy to be reoxidized. Methyl radicals also recombine to form $\mathrm{C}_{2} \mathrm{H}_{6}$ which dehydrogenates to $\mathrm{C}_{2} \mathrm{H}_{4}$. Unselective pathways include the interaction of hydrocarbons and intermediates with electrophilic surface and gas phase species [17], such as mentioned surface peroxo-species [4], or gas phase $\mathrm{O}_{2}$ [15].

One of the most promising and probably the best investigated [18] catalyst for OCM is $\mathrm{Li}$-doped $\mathrm{MgO}[15,19$ 21]. However, a recent review [22] reveals numerous wellperforming and promising catalyst compositions reported in literature so far. In the co-feed mode (simultaneously introducing $\mathrm{CH}_{4}$ and $\mathrm{O}_{2}$ into the reactor) $\mathrm{C}_{2}$-yields up to $25-27 \%$ have been reported over $\mathrm{RbWO}_{4} / \mathrm{SiO}_{2}$ and $\mathrm{Bi}_{1.5} \mathrm{Y}_{0.3} \mathrm{Sm}_{0.2} \mathrm{O}_{3-\delta}$ catalysts, respectively [23,24]. High yields on less selective catalysts can also be obtained by improved reaction engineering [25]. For example, yields in the range of $17-23 \%$ were reported when operating in a membrane reactor with an oxygen-ion conducting $\mathrm{La}_{0.8} \mathrm{Sr}_{0.2} \mathrm{Co}_{0.6} \mathrm{Fe}_{0.4} \mathrm{O}_{3-\delta}$ membrane separating the $\mathrm{CH}_{4}$ and $\mathrm{O}_{2}$ gas streams [26], or by alternating feed mode of $\mathrm{CH}_{4}$ and $\mathrm{O}_{2}$, e.g., over $\mathrm{Sr}_{0.75} \mathrm{Na}_{0.25} \mathrm{NiO}_{3-\delta}$ or $\mathrm{SrNi}_{0.75} \mathrm{Li}_{0.25} \mathrm{O}_{3-\delta}$ [27], even though applied perovskite-type and/or $\mathrm{Ni}$ containing catalysts are commonly used for catalyzing partial or total oxidation pathways of methane. However, a major lack of so far published catalytic data is the poor comparability among studies by different authors. For instance, as can be seen in Tab. 1, reaction temperatures, $\mathrm{CH}_{4} / \mathrm{O}_{2}$ ratios, and space velocities cover a broad range and make assembled data difficult to compare. Other important data such as conversion of $\mathrm{O}_{2}$ or stability with time-onstream are often not given.

Besides the chemical composition, also the preparation method could provide a certain potential for optimizing the catalyst activity and $\mathrm{C}_{2}$-yields. In recent studies, we could show that synthesis methods utilizing w/omicroemulsions [28] or cellulose filter papers [29] as structural templates for mixed metal oxides can significantly improve the catalytic properties of perovskite-type catalysts for oxidative methane activation as compared to conven- tional co-precipitation or sol-gel methods. The overall activity as well as the selectivity to $\mathrm{C}_{2}$ products can be influenced.

The present study aims at the improvement of $\mathrm{C}_{2}$ yields in the OCM reaction. Based on the elemental compositions and preparation recipes of best performing catalysts reported in literature this is intended to be realized by variation of the oxidizing agent and by applying cellulose templating (CT) as an alternative synthesis method to the respective method reported in literature. This study furthermore provides a direct comparison of catalytic performances of state-of-the-art catalysts reported in past literature.

\section{Experimental}

\subsection{Catalyst Selection and Preparation}

The catalysts investigated in the present study are listed in Tab. 1. They are selected according to their high $\mathrm{C}_{2}$ yields in the OCM reaction as reported in current literature. In a recent study [29] we modified perovskites compositions towards high ability to oxidatively activate $\mathrm{CH}_{4}$. With respect to their high activity and selectivity towards total methane combustion products these were employed for estimating the potential of $\mathrm{N}_{2} \mathrm{O}$ to form more OCM selective oxygen species at temperatures $>823 \mathrm{~K}$. Hereinafter, the catalysts are denoted with the elemental symbols of their metallic constituents without stochiometry but followed by (CT) or (lit) according to the cellulose templating or literature methods, respectively. For instance, the catalyst with the composition $\mathrm{BaF}_{2}(95 \mathrm{~mol} \%) / \mathrm{Y}_{2} \mathrm{O}_{3}$ prepared by the respective method reported in literature is labeled with BaY(lit).

For the preparation of CT-type catalysts, corresponding metal acetates and nitrates as well as ammonium salts of anionic precursors were dissolved in stochiometric amounts in deionized water. The solution $\left(0.35 \mathrm{~mol} \mathrm{~L}^{-1}\right)$ was carefully dripped onto filter paper (Whatman 50, low ash) in the ratio of $1.7 \mathrm{~mL} \mathrm{~g}^{-1}$ liquid per filter paper. Subsequently, without drying, the impregnated filter papers were transferred into a preheated muffle oven $(1273 \mathrm{~K})$ and calcined for $3 \mathrm{~h}$ in air [29].

Other samples were synthesized by calcination of catalyst precursors prepared by coprecipitation/impregnation ( $\mathrm{NaBaSrTi}, \mathrm{LiCeMg}$ ), incipient wetness impregnation ( $\mathrm{RbWSi}, \mathrm{NaWSi}, \mathrm{LiMg}$ ), citric acid sol-gel method (SrNaNi, SrNiLi, BiYSm) or calcination of precursor salt mixtures $(\mathrm{BaY}, \mathrm{LaCa}, \mathrm{NdCa})$. Details of preparation recipes are given in the respective references listed in Tab. 1. All chemicals were purchased from Fluka, Roth, and Merck with a purity grade of $>99 \%$ and were used without further purification. 
Table 1. Catalysts investigated in the present study and their performances in the OCM under different reaction conditions as reported in literature.

\begin{tabular}{|c|c|c|c|c|c|c|}
\hline Catalyst & $T(\mathrm{~K})$ & $\mathrm{CH}_{4}: \mathrm{O}_{2}$ :inert & $\operatorname{GHSV}\left(m L g^{-1} h^{-1}\right)$ & $X\left(\mathrm{CH}_{4}\right)(\%)$ & $S\left(C_{2}\right)(\%)$ & Ref. \\
\hline $\mathrm{BaF}_{2}(95 \mathrm{~mol} \%) / \mathrm{Y}_{2} \mathrm{O}_{3}$ & 1023 & $2,5: 1: 11$ & 6000 & 36,1 & 62,1 & {$[30]$} \\
\hline $\mathrm{Rb}_{2} \mathrm{WO}_{4}\left(0,3 \mathrm{mmol} \mathrm{g}^{-1}\right) / \mathrm{SiO}_{2}$ & 1123 & $4.5: 1$ & $2000^{2}$ & 32 & 78 & [23] \\
\hline $\mathrm{Na}_{2} \mathrm{WO}_{4}\left(0,3 \mathrm{mmolg}^{-1}\right) / \mathrm{SiO}_{2}$ & 1123 & $4,5: 1$ & $2000^{2}$ & 44 & 52 & [23] \\
\hline $\mathrm{NaMnO}_{4}(12.5 \mathrm{wt} \%) / \mathrm{MgO}$ & 1073 & $5: 1: 4$ & 4800 & $28^{\mathrm{b}}$ & 69 & [31] \\
\hline $\mathrm{Na}(0.32 \mathrm{~g}) / \mathrm{BaSrTiO}_{3}$ & 1073 & $2: 1: 2$ & $6000^{2}$ & 47 & 51 & [32] \\
\hline $\mathrm{Li}(0.2 \mathrm{wt} \%) / \mathrm{MgO}$ & 923 & $21: 1: 28$ & 6000 & 3.0 & 17.7 & {$[15]$} \\
\hline $\mathrm{SrCO}_{3} / \mathrm{La}_{2}\left(\mathrm{CO}_{3}\right)_{3}(\mathrm{La} ; \mathrm{Sr}-2)$ & 1153 & $10: 1: 0$ & 219,800 & $15,8^{b}$ & 80,8 & [33] \\
\hline $\mathrm{La}(5 \mathrm{~mol} \%) / \mathrm{CaO}$ & 1073 & $8: 1: 0$ & 51,360 & 19,8 & 67,2 & [34] \\
\hline $\mathrm{Nd}(5 \mathrm{~mol} \%) / \mathrm{CaO}$ & 1073 & $8: 1: 0$ & 51,360 & 19.5 & 70.8 & [34] \\
\hline $\mathrm{Li}(5 \mathrm{~mol} \%) / \mathrm{Ce}(0.5 \mathrm{~mol} \%) \mathrm{Mgo}$ & 1073 & $5: 1: 44$ & 6000 & 21,7 & 64,0 & {$[35]$} \\
\hline $\mathrm{Bi}_{1.5} \mathrm{Y}_{0.3} \mathrm{Sm}_{0.2} \mathrm{O}_{3-5}$ & 1223 & $2: 1: 3$ & 8955 & $42,4^{b}$ & 62,7 & {$[24]$} \\
\hline $\mathrm{Bi}_{1.5} \mathrm{Y}_{0.3} \mathrm{Sm}_{0.2} \mathrm{O}_{3-5}$ & 1173 & \multicolumn{2}{|c|}{$\begin{array}{l}\text { Membrane reactor, } 21 \% \mathrm{O}_{2} / \mathrm{N}_{2} \text { (oxygen side), } 2 \% \\
\mathrm{CH}_{4} / \mathrm{He} \text { (methane side) }\end{array}$} & 65,0 & 54,7 & [36] \\
\hline $\mathrm{Sr}_{0.3} \mathrm{La}_{0.7} \mathrm{MnO}_{\mathrm{x}}$ & 823 & $2: 1: 7$ & 30,000 & $28,5^{b}$ & $<5$ & [29] \\
\hline $\mathrm{Sr}_{0.4} \mathrm{La}_{0.5} \mathrm{Fe}_{0.2} \mathrm{Co}_{0.8} \mathrm{O}_{\mathrm{x}}$ & 823 & $2: 1: 7$ & 30,000 & 27,4 & $<5$ & [29] \\
\hline
\end{tabular}

\subsection{Catalyst Characterization}

For a detailed physico-chemical characterization of the large amount and diversity of catalysts tested, we refer to the respective literature listed in Tab. 1 as the focus of this study is the catalytic testing. However, selected catalyst samples showing a strongly different catalytic behavior (see Fig. 4) were subjected to repeated structural analyses after the catalytic tests after $40 \mathrm{~h}$ in OCM feed with $\mathrm{O}_{2}$ and $\mathrm{N}_{2} \mathrm{O}$ as the oxidizing agents at temperatures between $973-$ $1073 \mathrm{~K} . \mathrm{CO}_{2}$ has also been tested as a potential oxidizing agent, however, these experiments are described elsewhere [37]. The influences of the preparation method, the catalytic conditions or the nature of the oxidative agent thereon are discussed.

The specific surface areas of the catalyst samples were determined by $\mathrm{N}_{2}$ adsorption at $77 \mathrm{~K}$, using a Micromeritics 2375 BET apparatus equipped with a Vacprep 061 degasser. Before acquisition of the adsorption isotherm, the samples were first outgassed at $15 \mathrm{~Pa}$ and $393 \mathrm{~K}$ for $12 \mathrm{~h}$, to ensure a clean and dry surface. The specific surface areas were calculated from the BET equation from adsorption data in the range of $p / p_{0}=0.05-0.3$.

Powder X-ray diffraction (XRD) measurements were conducted in order to get information about crystalline phases and crystallite size in the catalysts. The XRD patterns of catalyst samples were obtained using a STOE STADI-P transmission diffractometer with a focusing primary $\mathrm{Ge}(111)$ monochromator applying $\mathrm{Cu} \mathrm{K} \alpha$ radiation $(\lambda$ $=1.5406 \AA$ ) and a scanning angle $(2 \theta)$ range of $10-90^{\circ}$.

A Hitachi S-4800 instrument with an EDAX Genesis EDX detector was used for scanning electron microscopy (SEM) studies. The samples were deposited on carbon tape. Images were acquired at $2 \mathrm{kV}$ to optimize surface resolution, while energy dispersive X-ray spectroscopy (EDX) was carried out with an accelerating voltage of $15 \mathrm{kV}$.

\subsection{Catalyst Testing}

Catalytic tests on the OCM reaction were carried out in a multi-channel reactor system located at LIKAT (Rostock). This set-up consists of 48 plug flow fixed-bed quartz reactors with an inner diameter of $4 \mathrm{~mm}$ operating in parallel. The feed gas mixtures, as introduced one after the other at atmospheric pressure, comprised $\mathrm{CH}_{4} /$ air, $\mathrm{CH}_{4} / \mathrm{N}_{2} \mathrm{O} / \mathrm{Ar}$, and $\mathrm{CH}_{4} / \mathrm{CO}_{2} / \mathrm{N}_{2}$ mixtures in stochiometric $\mathrm{O} / \mathrm{C}=1$ ratio with regard to the OCM reaction while keeping the $\mathrm{CH}_{4}$ concentration constant, i.e., $\mathrm{CH}_{4}: \mathrm{O}_{2}: \mathrm{N}_{2}=2: 1: 4$, $\mathrm{CH}_{4} / \mathrm{N}_{2} \mathrm{O} / \mathrm{Ar}=2: 2: 3$, and $\mathrm{CH}_{4}: \mathrm{CO}_{2}: \mathrm{N}_{2}=2: 2: 3$. The catalyst grains $(250-300 \mu \mathrm{m})$ were diluted with quartz sand (except for the respective reactors with lowest GHSV) and filled into each reactor. One empty reactor was chosen to account for the detection of gas phase reactions and analysis of educt gas composition was realized by a bypass line. An inhouse developed flow restrictor equally distributed the total gas flow to the 48 reactors with a constant single reactor flow of $15 \mathrm{~mL} \mathrm{~min}^{-1}$. A variation of space velocity was realized by using different amounts of catalysts in parallel operating reactors. Thus, using catalyst masses between 50 and $500 \mathrm{mg}$, gas hourly space velocities (GHSV) of 3,600$100,000 \mathrm{~h}^{-1}$ were adjusted. The catalysts were heated in $\mathrm{Ar}$ up to $973 \mathrm{~K}$ and then brought in contact with the reactant feed. For each oxidizing agent, reactor temperatures of 973 , 1023, and $1073 \mathrm{~K}$ were adjusted. Each temperature was held for approx. $12 \mathrm{~h}$ corresponding to 3 measuring points of product gas composition.

The feed components and the reaction products were analyzed by an online gas chromatograph (Agilent 7890) equipped with PLOT/Q (for $\mathrm{CO}_{2}$ and $\mathrm{N}_{2} \mathrm{O}$ ), AL/S (for hydrocarbons) and Molsieve 5 (for $\mathrm{H}_{2}, \mathrm{O}_{2}, \mathrm{~N}_{2}$, and $\mathrm{CO}$ ) columns as well as flame ionization and thermal conductivity detectors. The conversion of $\mathrm{CH}_{4}$ was calculated from the inlet and outlet concentrations of $\mathrm{CH}_{4}$. The product selectivities were calculated on the product basis. The GC analysis started after the system had reached reaction temperature and was carried out sequentially for each individual reactor. 
Table 2. Specific surface areas of selected catalysts.

\begin{tabular}{|c|c|c|c|}
\hline Catalyst & $S_{\text {BET }}\left(\mathrm{m}^{2} \mathrm{~g}^{-1}\right)$ & $S_{\text {BET,lit }}\left(\mathrm{m}^{2} \mathrm{~g}^{-1}\right)$ & Ref. \\
\hline NaWSi(lit) & 1,2 & -2 & [23] \\
\hline BaY(lit) & 2,0 & 1.1 & [30] \\
\hline LiMg(lit) & 0.1 & 37 & [15] \\
\hline $\operatorname{LiMg}(\mathrm{CT})$ & 12.7 & $16^{b}$ & [38] \\
\hline SrLaFeCo(CT) & 1,7 & 11.9 & [29] \\
\hline
\end{tabular}

\section{Results and Discussion}

\subsection{Catalyst Characterization}

\subsection{1. $\mathrm{N}_{2}$ physisorption and X-ray Diffraction}

Characterization results presented herein were selected according to the catalysts OCM behavior by employing the criteria as mentioned in section 2.2. Briefly, during OCM with $\mathrm{O}_{2}$ at $1073 \mathrm{~K}, \mathrm{NaWSi}($ lit), $\mathrm{LiMg}($ lit), and BaY(lit) provide highest $\mathrm{C}_{2}$ selectivities around $40 \%$ at different degrees of methane conversion in the range of 30$50 \%$. Contrarily, $\operatorname{LiMg}(\mathrm{CT})$ shows a $\mathrm{C}_{2}$ selectivity of only $16 \%$ at the similar level of $\mathrm{CH}_{4}$ conversion. The perovskite $\mathrm{SrLaFeCo}(\mathrm{CT})$ provides a methane conversion of $30 \%$, which is limited by full $\mathrm{O}_{2}$ conversion, at almost zero $\mathrm{C}_{2}$ selectivity. Specific surface areas of these catalysts are listed in Tab. 2. The comparison with literature data shows that all catalysts provide a low surface area after long term catalytic tests in OCM reaction. Especially for $\mathrm{LiMg}(\mathrm{lit})$, $\mathrm{LiMg}(\mathrm{CT})$, and $\mathrm{SrLaFeCo}$ (lit) a dramatic difference is observed. For BaY(lit), low surface areas are explained by sintering effects during high temperature treatment [30] and it is assumed that this is also the reason for structural collapse of other catalysts investigated. Accordingly, the high surface area of $\mathrm{LiMg}(\mathrm{lit})$ was measured after a reaction time of $3 \mathrm{~h}$ at the low temperature of $923 \mathrm{~K}$ [15]. However, even though showing a lower $\mathrm{C}_{2}$-selectivity in comparison to $\operatorname{LiMg}($ lit), the structural stability of $\operatorname{LiMg}(\mathrm{CT})$ is remarkable and the sample keeps the relatively high surface area of $>12 \mathrm{~m}^{2} \mathrm{~g}^{-1}$ even after long term reaction conditions.

Comparing the crystallographic data gained from XRD analysis over fresh and used catalysts reveals significant restructuring induced by being applied to OCM reaction for $40 \mathrm{~h}$ on stream; solely the LiMg samples are phase stable under the above conditions. Owing to the low $\mathrm{Li}$ loading the diffractograms of $\operatorname{LiMg}$ (lit) and $\operatorname{LiMg}(\mathrm{CT}$ ) (not shown) disclose phase-pure $\mathrm{MgO}$ according to powder diffraction file PDF 00-043-1022. The peak analysis according to Scherrer [39] gives an estimate of the mean crystallite sizes of 188 and $114 \mathrm{~nm} \mathrm{[40]} \mathrm{for} \operatorname{LiMg}($ lit) and $\mathrm{LiMg}(\mathrm{CT})$, respectively. This correlates well with the higher surface area of the CT sample and underlines the advantages of the cellulose template method for the synthesis of highly dispersed and structurally stable oxidic structures [38]. The BaY(lit) sample (see Fig. 1) comprises $\mathrm{BaF}_{2}$
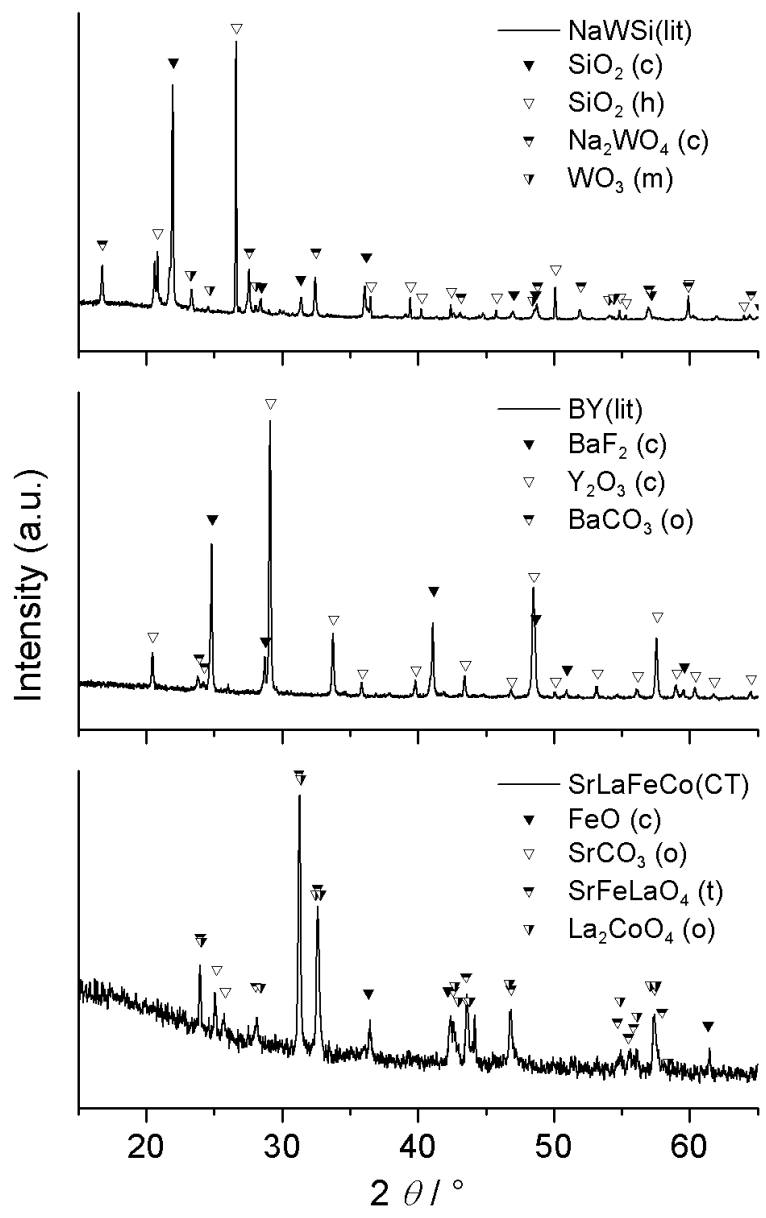

Figure 1. XRD patterns of NaWSi(lit), BaY(lit), and SrLa$\mathrm{FeCo}(\mathrm{CT})$ catalysts after use in OCM for $40 \mathrm{~h}$ on stream, reaction conditions as listed in section 2.3. Modifications are given in parenthesis: cubic (c), hexagonal (h), monoclinic (m), orthorhombic (o), tetragonal (t).

(PDF 00-085-1342) and $\mathrm{Y}_{2} \mathrm{O}_{3}$ (PDF 00-041-1105) phases and a small amount of $\mathrm{BaCO}_{3}$ (PDF 00-044-1487). The stability of the precursor phases is reported in literature [30], however, the presence of a carbonate phase indicates the slow transformation of $\mathrm{BaF}_{2}$ to $\mathrm{BaCO}_{3}$ in the presence of $\mathrm{CO}_{2}$, which is a by-product of OCM. This questions the stability of $\mathrm{BaY}$ (lit) at extended OCM reaction periods, although the formation of $\mathrm{BaCO}_{3}$ could also be accelerated by the experiments using $\mathrm{CO}_{2}$ in high concentration as the oxidizing agent [37].

The NaWSi(lit) catalyst comprises two different modifications of the $\mathrm{SiO}_{2}$ support, namely cubic cristobalite (PDF 00-001-0438) and tetragonal quartz (PDF 00-0331161 ), whereas in the original report only the christobalite phase is detected [23]. More importantly, a small amount of $\mathrm{WO}_{3}$ (PDF 00-030-1387) can be identified by XRD, suggesting that $\mathrm{Na}_{2} \mathrm{WO}_{4}$ (PDF 00-012-0772) is unstable under the reaction conditions applied. The least structurally stable catalyst is $\mathrm{SrLaFeCo}(\mathrm{CT})$, which completely decomposes into $\mathrm{FeO}$ (PDF 00-001-1223), $\mathrm{SrCO}_{3}$ (PDF 00-005-0418) as well as several binary and ternary mixed oxide phases, 

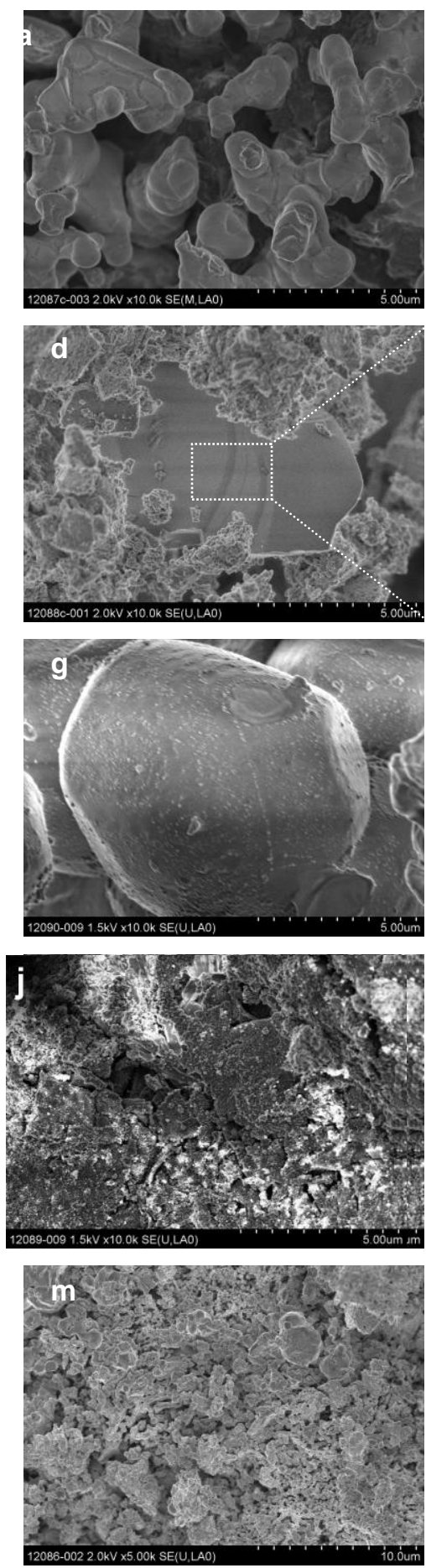
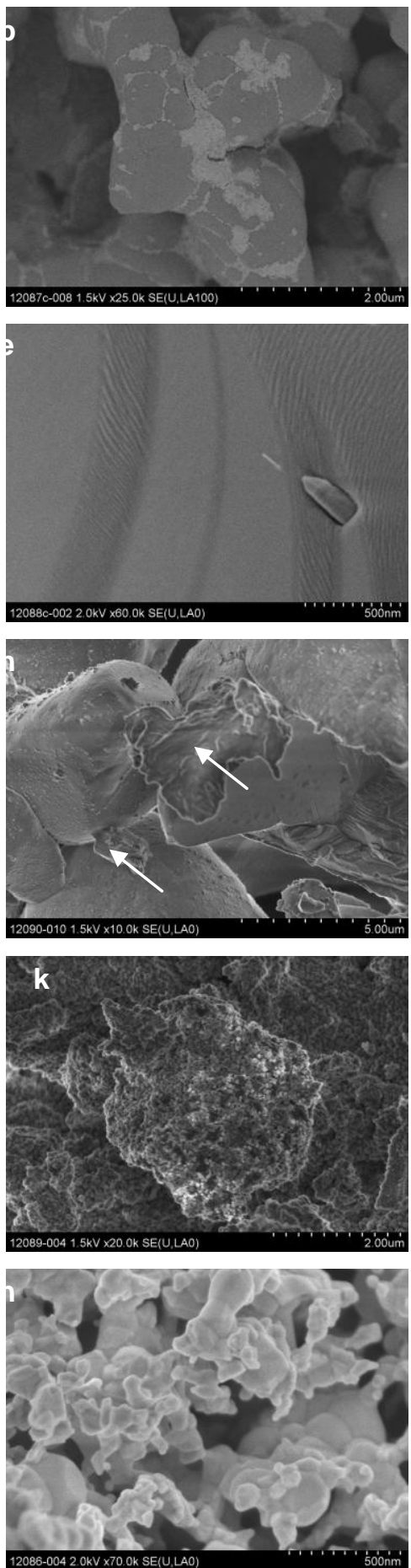
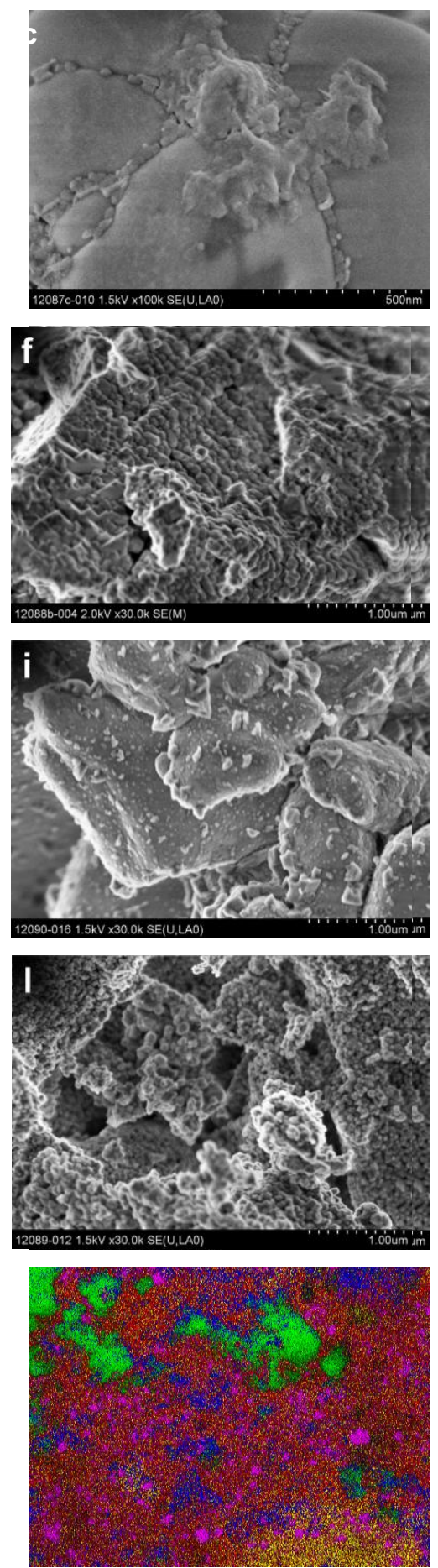

Figure 2. SEM images of NaWSi(lit) (a-c), BaY(lit) (d-f), $\operatorname{LiMg}($ lit) (g-i), $\operatorname{LiMg}(\mathrm{CT})(\mathrm{j}-1)$, and $\operatorname{SrLaFeCo}(\mathrm{CT})$ (m-n) catalysts after use in OCM for $40 \mathrm{~h}$ on stream under varying reaction conditions. The elemental mapping of $\mathrm{SrLaFeCo}(\mathrm{CT})$ (o) shows section $(\mathrm{m})$ and indicates enrichment of $\mathrm{Sr}$ (green), $\mathrm{La}$ (red), $\mathrm{Fe}$ (yellow), Co (magenta), and $\mathrm{O}$ (blue).

which are difficult to identify in detail. Although the ICSD database [41] provides numerous similar patterns containing the elements of the perovskite, the typical reflexes of $\mathrm{SrFeLaO}_{4}$ (PDF 00-029-1305) and $\mathrm{La}_{2} \mathrm{CoO}_{4}$ (PDF 00-0341081) are given as references. The signal-to-noise ratio detected in the diffraction patterns of the fresh SrLa$\mathrm{FeCo}(\mathrm{CT})$ (as can be taken from [29]) is lower compared to that of used $\mathrm{SrLaFeCo}(\mathrm{CT})$ depicted in Fig. 1. This may demonstrate a loss of crystallinity, which is in line with the structural collapse of the material.

\subsubsection{Scanning Electron Microscopy}

The SEM and EDX analyses of the used catalysts are shown in Fig. 2. The porous structure of NaWSi(lit) (Fig. 
2a) is conserved from the porous $\mathrm{SiO}_{2}$ support used for impregnation even after $40 \mathrm{~h}$ on OCM conditions. The elements are macroscopically well dispersed over the catalyst particles as pointed out by EDX analysis and backscattered SEM (Fig. 2b). $\mathrm{Na}_{2} \mathrm{WO}_{4}$ is dispersed on the smooth $\mathrm{SiO}_{2}$ surface in $50-500 \mathrm{~nm}$ sized clusters (Fig. 2c). Traces of $\mathrm{C}$ are mainly located on the $\mathrm{SiO}_{2}$ surface, whereas the W- and Na-rich areas are almost free of C. BaY(lit) (Fig. 2d) remains a physical mixture of plain shaped $\mathrm{BaF}_{2}$ crystals (Fig. 2e) and $\mathrm{Y}_{2} \mathrm{O}_{3}$ (Fig. 2f), which provides a rough surface. In agreement with the phase analysis by XRD, the elemental mapping reveals the coherence of $\mathrm{Ba}$ and $\mathrm{F}$, as well as $\mathrm{Y}$ and $\mathrm{O}$. Traces of $\mathrm{C}$ can be detected on both $\mathrm{BaF}_{2}$ and $\mathrm{Y}_{2} \mathrm{O}_{3}$ materials.

The LiMg catalysts show clear differences in their microstructure. $\mathrm{LiMg}(\mathrm{lit})$ conserved the $\sim 5 \mu \mathrm{m}$ sized spherical $\mathrm{MgO}$ particles with smooth surfaces (Figs. $2 \mathrm{~g}$ and h), whereas $\operatorname{LiMg}(\mathrm{CT})$ appears less ordered and provides rough surfaces (Figs. 2j-1) in agreement with the higher specific surface area owing to the CT method (Tab. 2). However, the latter misses the typical cellulose templated structure observed for other mixed oxides [29], which is probably due to sintering processes during reaction. On both samples Li cannot be detected by EDX due to the low loading of $0.2 \mathrm{wt} \%$ and the low atomic mass of Li. However, both samples provide a strong $\mathrm{C}$ signal, which is even more pronounced on the $\operatorname{LiMg}(\mathrm{CT})$ sample. It is also confirmed by optical analysis of used catalysts, whose colors are grey and white for $\operatorname{LiMg}(\mathrm{CT})$ and $\operatorname{LiMg}($ lit $)$ samples, respectively. On $\mathrm{LiMg}$ (lit) carbon is present in the form of bigger flakes (Figs. $2 \mathrm{~g}$ and h, arrows), whereas on the CT sample it appears to be more homogeneously distributed. The latter fact may hint towards $\mathrm{C}$ to be partly present as an artifact of the cellulose template. The primary particle size of $\mathrm{MgO}$ crystallites in both samples is in the range of 100$200 \mathrm{~nm}$ (Figs. 2i and 1) in agreement with XRD analysis.

The most drastic structural collapse is observed for the $\mathrm{SrLaFeCo}(\mathrm{CT})$ catalyst, as indicated by the XRD analysis. The nicely adapted cellulose structure (as had been observed in [29]) is completely destroyed and sintered to form a less porous microstructure (Fig. $2 \mathrm{~m}$ and $\mathrm{n}$ ). The metallic constituents of the homogeneously substituted perovskite segregated to form crystallites and clusters of varying composition, mainly oxides and carbonates as illustrated in the element map (Fig. 2o). The average chemical composition as determined by EDX, however, still represents the stochiometry of the perovskite (Sr: 21.6 at\%, La: 30.6 at\%, Fe: 9.6 at\%, Co: 38.2 at\%). Only small amounts of $\mathrm{C}$ can be detected on the $\mathrm{SrLaFeCo}(\mathrm{CT})$ sample.

\subsection{Catalytic Testing}

\subsection{1. $\mathrm{Li}_{2} \mathrm{O} / \mathrm{MgO}$ based catalysts}

The catalytic performances of pure as well as $\mathrm{Zr}$ and Ce doped $\mathrm{Li}_{2} \mathrm{O} / \mathrm{MgO}$ catalysts are shown in Tab. 1. The stability is given as the temporal change of absolute activity
Table 3. Catalytic performances of $\mathrm{L}_{2} \mathrm{O} / \mathrm{MgO}$-based catalysts in the reactions of $\mathrm{CH}_{4}$ with $\mathrm{O}_{2}$ and $\mathrm{N}_{2} \mathrm{O}$, respectively, $(\mathrm{O} / \mathrm{C}=1)$ at $1073 \mathrm{~K}$ and GHSV 3,600 $\mathrm{h}^{-1}$.

\begin{tabular}{|c|c|c|c|c|}
\hline Catalyst & Oxidiz ing agent & $X\left(\mathrm{CH}_{4}\right)(\%)$ & $S\left(C_{2}\right)(\%)$ & $\Delta X / \Delta t\left(\mathrm{\%}^{-1}\right)$ \\
\hline \multirow[t]{2}{*}{ LiMg(lit) } & $\mathrm{O}_{2}$ & 41,4 & 37,3 & $-0,33$ \\
\hline & $\mathrm{N}_{2} \mathrm{O}$ & 9.0 & 55.2 & $-0,08$ \\
\hline \multirow[t]{2}{*}{$\operatorname{LiMg}(\mathrm{CT})$} & $\mathrm{O}_{2}$ & 28,1 & 12,9 & $-0,45$ \\
\hline & $\mathrm{N}_{2} \mathrm{O}$ & 27.0 & 9.7 & $+0,02$ \\
\hline \multirow[t]{2}{*}{ LiMgZr(CT) } & $\mathrm{O}_{2}$ & 27.4 & 15.2 & $-0,38$ \\
\hline & $\mathrm{N}_{2} \mathrm{O}$ & 30,6 & 41,7 & $-0,03$ \\
\hline \multirow[t]{2}{*}{ LiMgCe(lit) } & $\mathrm{O}_{2}$ & 43.0 & 37.0 & -0.01 \\
\hline & $\mathrm{N}_{2} \mathrm{O}$ & 34,3 & 41.9 & $-0,01$ \\
\hline \multirow[t]{2}{*}{$\operatorname{LiMgCe}(\mathrm{CT})$} & $\mathrm{O}_{2}$ & 40,3 & 28,6 & -0.08 \\
\hline & $\mathrm{N}_{2} \mathrm{O}$ & 33.7 & 36.4 & $+0,04$ \\
\hline
\end{tabular}

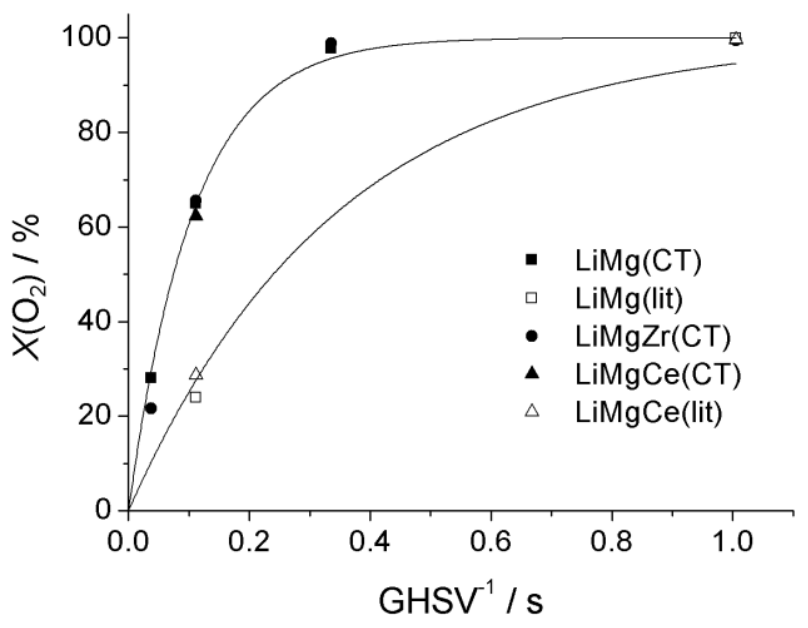

Figure 3. Conversions of $\mathrm{O}_{2}$ in the OCM over LiMg-based catalysts at $1073 \mathrm{~K}$.

in terms of $\mathrm{CH}_{4}$ conversion $\mathrm{d} X / \mathrm{d} t$ within $10 \mathrm{~h}$ on stream under the respective reaction conditions. In general, the use of $\mathrm{O}_{2}$ as the oxidizing agent leads to higher conversions of $\mathrm{CH}_{4}$ than $\mathrm{N}_{2} \mathrm{O}$ except for $\mathrm{LiMgZr}(\mathrm{CT})$. Full conversion of $\mathrm{O}_{2}$ and $\mathrm{N}_{2} \mathrm{O}$, respectively, at the GHSV of $3600 \mathrm{~h}^{-1}$ is observed in each case. $\mathrm{N}_{2} \mathrm{O}$ is totally converted except over $\mathrm{LiMg}$ (lit). It is seen that the CT catalysts provide lower conversions of $\mathrm{CH}_{4}$ than the catalysts prepared by recipes from literature [15,35]. With regard to the full conversion of $\mathrm{O}_{2}$, this can be directly correlated to the lower selectivity because the total oxidation of $\mathrm{CH}_{4}$ consumes more $\mathrm{O}_{2}$ than the selective OCM. The doped CT catalysts provide a higher $\mathrm{C}_{2}$ selectivity and also a higher stability over the pure $\mathrm{LiMg}(\mathrm{CT}) . \mathrm{ZrO}_{2}$ and $\mathrm{CeO}_{2}$ are known as red-ox promotors and structural stabilizers, which can enhance the catalytic performance of active components [42].

Also the oxidizing agent has a remarkable impact on the stability of the samples. $\mathrm{O}_{2}$ leads to a rapid activity loss in most cases, which is well-known for $\mathrm{Li}_{2} \mathrm{O} / \mathrm{MgO}$ catalysts $[19,43]$. Contrarily, the use of $\mathrm{N}_{2} \mathrm{O}$ apparently prevents the deactivation by $\mathrm{O}_{2}$. In some cases even an increase in activity with time on stream was observed $(\Delta X / \Delta t>0)$. The lower oxidation strength of $\mathrm{N}_{2} \mathrm{O}$ also lowers the areal rate of $\mathrm{CH}_{4}$ conversion (see Tab. 3). Moreover, the formation of more selective $\mathrm{O}$ species on the catalyst surface when using 
Table 4. Catalytic performances of alkaline tungstate catalysts in the reactions of $\mathrm{CH}_{4}$ with $\mathrm{O}_{2}$ and $\mathrm{N}_{2} \mathrm{O}$, respectively, $(\mathrm{O} / \mathrm{C}=1)$ at $1073 \mathrm{~K}$ and GHSV $3,600 \mathrm{~h}^{-1}$.

\begin{tabular}{llcll}
\hline Catalyst & Oxidizing agent & $X\left(\mathrm{CH}_{4}\right) / \%$ & $S\left(\mathrm{C}_{2}\right) / \%$ & $\Delta X / \Delta t / \% \mathrm{~h}^{-1}$ \\
\hline \multirow{2}{*}{$\mathrm{NaWSi}(\mathrm{lit})$} & $\mathrm{O}_{2}$ & 4,9 & 14,2 & $-0,05$ \\
& $\mathrm{~N}_{2} \mathrm{O}$ & 4,3 & 83,4 & $-0,16$ \\
$\mathrm{NaWSi}(\mathrm{CT})$ & $\mathrm{O}_{2}$ & 32,1 & 25,5 & $+0,19$ \\
& $\mathrm{~N}_{2} \mathrm{O}$ & 21,3 & 49,5 & $-0,05$ \\
\multirow{2}{*}{ RbWSi(lit) } & $\mathrm{O}_{2}$ & 29,7 & 45,3 & $-0,12$ \\
& $\mathrm{~N}_{2} \mathrm{O}$ & 3,8 & 73,5 & $-0,12$ \\
RbWSi(CT) & $\mathrm{O}_{2}$ & 31,8 & 29,9 & +0.06 \\
& $\mathrm{~N}_{2} \mathrm{O}$ & 27,0 & 42,1 & $-0,03$ \\
\hline
\end{tabular}

Table 5. Catalytic performances of earth alkaline and lanthanide oxides in the reactions of $\mathrm{CH}_{4}$ with $\mathrm{O}_{2}$ and $\mathrm{N}_{2} \mathrm{O}$, respectively, $(\mathrm{O} / \mathrm{C}$ $=1)$ at $1073 \mathrm{~K}$ and GHSV $3,600 \mathrm{~h}^{-1}$.

\begin{tabular}{|c|c|c|c|c|c|}
\hline Catalyst & $\begin{array}{l}\text { Oxidizing } \\
\text { agent }\end{array}$ & $X\left(\mathrm{CH}_{4}\right)(\%)$ & $S\left(C_{2}\right)(\%)$ & $S\left(C_{2}\right)^{2}(\%)$ & $\Delta X / \Delta t\left(\% \mathrm{~h}^{-1}\right)$ \\
\hline SrLa(lit) & $\begin{array}{l}\mathrm{O}_{2} \\
\mathrm{~N}_{2} \mathrm{O}\end{array}$ & $\begin{array}{l}32,6 \\
26,7\end{array}$ & $\begin{array}{l}18,9 \\
20.0\end{array}$ & $\begin{array}{l}22,1 \\
28.5\end{array}$ & $\begin{array}{l}-0.19 \\
-0.01\end{array}$ \\
\hline $\operatorname{SrLa}(C T)$ & $\begin{array}{l}\mathrm{O}_{2} \\
\mathrm{~N}_{2} \mathrm{O}\end{array}$ & $\begin{array}{l}37.5 \\
29,8\end{array}$ & $\begin{array}{l}22.2 \\
26.8\end{array}$ & $\begin{array}{l}29,1 \\
31,1\end{array}$ & $\begin{array}{l}-0,07 \\
+0,02\end{array}$ \\
\hline LaCa(lit) & $\begin{array}{l}\mathrm{O}_{2} \\
\mathrm{~N}_{2} \mathrm{O}\end{array}$ & $\begin{array}{l}35,9 \\
29,9\end{array}$ & $\begin{array}{l}16.7 \\
24.3\end{array}$ & $\begin{array}{l}21,4 \\
32,1\end{array}$ & $\begin{array}{l}-0.01 \\
-0.01\end{array}$ \\
\hline $\mathrm{LaCa}(\mathrm{CT})$ & $\begin{array}{l}\mathrm{O}_{2} \\
\mathrm{~N}_{2} \mathrm{O}\end{array}$ & $\begin{array}{l}28.8 \\
27.5\end{array}$ & $\begin{array}{c}1.07 \\
18.5\end{array}$ & $\begin{array}{r}9,4 \\
19,9\end{array}$ & $\begin{array}{l}+0,06 \\
-0,01\end{array}$ \\
\hline $\mathrm{NdCa}(\mathrm{lit})$ & $\begin{array}{l}\mathrm{O}_{2} \\
\mathrm{~N}_{2} \mathrm{O}\end{array}$ & $\begin{array}{l}32,9 \\
30,2\end{array}$ & $\begin{array}{l}12.0 \\
28.4\end{array}$ & $\begin{array}{l}20,9 \\
28,6\end{array}$ & $\begin{array}{l}-0,05 \\
+0,02\end{array}$ \\
\hline $\mathrm{NdCa}(\mathrm{CT})$ & $\begin{array}{l}\mathrm{O}_{2} \\
\mathrm{~N}_{2} \mathrm{O}\end{array}$ & $\begin{array}{l}33.5 \\
29.8\end{array}$ & $\begin{array}{l}13.4 \\
30,6\end{array}$ & $\begin{array}{l}21,1 \\
35,0\end{array}$ & $\begin{array}{l} \pm 0 \\
+0,02\end{array}$ \\
\hline
\end{tabular}

2 GHSV $32,000 \mathrm{~h}^{-1}$

$\mathrm{N}_{2} \mathrm{O}$ as the oxidizing agent lowers the local heat production since the reaction enthalpy for selective OCM reaction is lower than that of the $\mathrm{CH}_{4}$ combustion. Thus it is assumed that the hot spot in the catalyst bed is more pronounced in the OCM with $\mathrm{O}_{2}$, which could be one reason for the differences in deactivation behavior. Accordingly, the thermally induced deactivation of the $\operatorname{LiMg}(\mathrm{CT})$ catalyst in OCM with $\mathrm{O}_{2}$, i.e., sintering and/or evaporation of Li [18], is only $0.04 \% \mathrm{~h}^{-1}$ at $1023 \mathrm{~K}$ and $0.002 \% \mathrm{~h}^{-1}$ at $973 \mathrm{~K}$, even though full $\mathrm{O}_{2}$ conversion is obtained in each case.

In this view the origin of the lower stabilities and the lower $\mathrm{C}_{2}$ selectivities obtained over the CT catalysts are assumed in their relatively high surface area leading to heat transfer limitations, which could favor secondary combustion of formed $\mathrm{C}_{2}$ products [44] and thus explain the lower selectivity observed on these samples. The conversions of $\mathrm{O}_{2}$ at $1073 \mathrm{~K}$ are compared in Fig. 3 and it is seen that the global rates are by a factor of approx. 2 higher on the CT catalysts irrespective of the doping, which apparently only affects the product selectivities.

\subsubsection{Tungstate catalysts}

Methane conversions, $\mathrm{C}_{2}$ selectivities as well as catalytic stability of NaWSi and RbWSi samples are shown in Tab. 4. The CT method leads to slightly higher conversions in the OCM with $\mathrm{O}_{2}$. Generally, OCM activity with $\mathrm{N}_{2} \mathrm{O}$ as the oxidizing agent is exceeding that of OCM with $\mathrm{O}_{2}$. The higher activity of CT prepared catalysts is attributed to the fine dispersion of tungstate ions over the catalyst bulk and surface as a result of the CT method. This provides an ideal distribution of the metal cations on a molecular level in the salt solutions prior to the impregnation of the template [45]. Instead, the incipient wetness impregnation reported in literature [23] yields agglomerates of alkaline tungstates on the $\mathrm{SiO}_{2}$ surface (Fig. 2b and c).

Contrarily to the $\mathrm{Li}_{2} \mathrm{O} / \mathrm{MgO}$ based catalysts, the tungstates tend to be more stable in the $\mathrm{O}_{2}$ containing feed and deactivate in the OCM feed with $\mathrm{N}_{2} \mathrm{O}$. Especially for the CT catalysts, a gain in activity is observed for the reaction with $\mathrm{O}_{2}$. Even more importantly the $\mathrm{C}_{2}$ selectivity also increases with time-on-stream indicating that the maximum performance of these catalysts is not equilibrated even after $40 \mathrm{~h}$ reaction time. The loss of activity of the $\mathrm{NaWSi}$ (lit) sample can possibly be attributed to the decomposition of the $\mathrm{Na}_{2} \mathrm{WO}_{4}$ phase to $\mathrm{WO}_{3}$ (Fig. 1).

\subsubsection{Earth alkaline and lanthanide oxides}

The catalytic performance of earth alkaline and lanthanide oxide catalysts tested in this study is assembled in Tab. 5. At $1073 \mathrm{~K}$ and GHSV of $3,600 \mathrm{~h}^{-1}$, all catalysts showed full $\mathrm{O}_{2}$ conversion as it is also valid for the almost tenfold lower contact time (GHSV 32,000 h${ }^{-1}$ ). The $\mathrm{CH}_{4}$ conversion is lower for $\mathrm{N}_{2} \mathrm{O}$ than $\mathrm{O}_{2}$ as the oxidizing agent and almost unaffected by contact time in this regime free of oxidative compounds. However, the $\mathrm{C}_{2}$ selectivity significantly increases with decreasing contact times. From that, we suggest that the catalytic performance shown in Tab. 5 is far from optimum conditions. As shown in Tab. 1, a $\mathrm{CH}_{4}: \mathrm{O}_{2}$ feed ratio $>2$ is frequently observed for this class of catalysts. The catalysts of this group are very stable under the reaction conditions applied.

Although full conversion of the oxidizing agent is also observed in all experiments with $\mathrm{N}_{2} \mathrm{O}$, the conversions of $\mathrm{CH}_{4}$ are higher in the presence of $\mathrm{O}_{2}$ regardless the same $\mathrm{C} / \mathrm{O}$ feed ratio in these comparative experiments and the higher $\mathrm{C}_{2}$ selectivities obtained with $\mathrm{N}_{2} \mathrm{O}$. However, with regard to the secondary degradation of $\mathrm{C}_{2}$ products as mentioned above, the latter might be the result of a slower overall reaction and not necessarily points at a different (more selective) $\mathrm{O}$ species formed by $\mathrm{N}_{2} \mathrm{O}$. In each case it is assumed that even at the short contact times significant coking occurs on these highly active catalysts. Unfortunately, shorter contact times have not been realized in the experimental program. The $\mathrm{CT}$ method provides slight advantages in terms of $\mathrm{CH}_{4}$ conversion and $\mathrm{C}_{2}$ selectivity for $\mathrm{SrLa}$ and $\mathrm{NdCa}$ samples, whereas the preparation method reported in literature [34] appears to be the better choice in case of the $\mathrm{LaCa}$ catalyst. 
Table 6. Catalytic performances of halogenide containing catalysts in the reactions of $\mathrm{CH}_{4}$ with $\mathrm{O}_{2}$ and $\mathrm{N}_{2} \mathrm{O}$, respectively, $(\mathrm{O} / \mathrm{C}=1)$ at $1073 \mathrm{~K}$ and GHSV $3,600 \mathrm{~h}^{-1}$

\begin{tabular}{|c|c|c|c|c|}
\hline Catalyst & Oxidizing agent & $X\left(\mathrm{CH}_{4}\right)(\%)$ & $S\left(C_{2}\right)(\%)$ & $\Delta X / \Delta t\left(\mathrm{\%}^{-1}\right)$ \\
\hline \multirow[t]{2}{*}{ BiYSm(lit) } & $\mathrm{O}_{2}$ & 34,7 & 23.5 & +0.12 \\
\hline & $\mathrm{N}_{2} \mathrm{O}$ & 27.0 & 23,0 & \pm 0 \\
\hline \multirow{2}{*}{$\operatorname{BiYSm}(\mathrm{CT})$} & $\mathrm{O}_{2}$ & 27.5 & 5.0 & -0.03 \\
\hline & $\mathrm{N}_{2} \mathrm{O}$ & 23.5 & 3.3 & -0.01 \\
\hline \multirow[t]{2}{*}{ NaMnMg(lit) } & $\mathrm{O}_{2}$ & 33.7 & 22,4 & $+0,09$ \\
\hline & $\mathrm{N}_{2} \mathrm{O}$ & 16.7 & 29.3 & -0.28 \\
\hline \multirow[t]{2}{*}{$\operatorname{NaMnMg}(\mathrm{CT})$} & $\mathrm{O}_{2}$ & 28,6 & 0.7 & +0.19 \\
\hline & $\mathrm{N}_{2} \mathrm{O}$ & 22.6 & 1.4 & $-0,01$ \\
\hline \multirow[t]{2}{*}{ BaY(lit) } & $\mathrm{O}_{2}$ & 45,4 & 40,7 & $+0,05$ \\
\hline & $\mathrm{N}_{2} \mathrm{O}$ & 22,9 & 67,0 & -0.25 \\
\hline \multirow[t]{2}{*}{$\mathrm{BaY}(\mathrm{CT})$} & $\mathrm{O}_{2}$ & 27.4 & 8.7 & -0.01 \\
\hline & $\mathrm{N}_{2} \mathrm{O}$ & 21,8 & 9.3 & $-0,18$ \\
\hline \multirow[t]{2}{*}{ NaBaSrTi(lit) } & $\mathrm{O}_{2}$ & 6,7 & 9.3 & -0.73 \\
\hline & $\mathrm{N}_{2} \mathrm{O}$ & 2.9 & 0.0 & -0.17 \\
\hline \multirow{2}{*}{ NaBaSrTi(CT) } & $\mathrm{O}_{2}$ & 28,1 & 0.0 & -0.09 \\
\hline & $\mathrm{N}_{2} \mathrm{O}$ & 26.4 & 0.0 & -0.02 \\
\hline
\end{tabular}

\subsubsection{BiYSm, NaMnMg, and halogenide containing catalysts}

Catalytic data of halogenide containing catalysts as well as the $\mathrm{NaMnMg}$ and BiYSm samples are listed in Tab. 6. In general, the reaction with $\mathrm{N}_{2} \mathrm{O}$ is slower as compared to $\mathrm{O}_{2}$. However, for the BiYSm catalysts $\mathrm{C}_{2}$ selectivities are lower at the lower conversions of $\mathrm{CH}_{4}$ indicating that active sites (re)generated by $\mathrm{N}_{2} \mathrm{O}$ are less selective than those (re)generated by $\mathrm{O}_{2}$. A very poor performance is observed for the $\mathrm{NaMnMg}(\mathrm{CT})$ sample, which provides lowest $\mathrm{C}_{2}$ selectivities. It suggests that highly oxidizing permanganate ions are reduced to $\mathrm{Mn}^{2+/ 3+}$ during the CT synthesis and released oxygen is consumed for the combustion of the cellulose template. Instead the impregnated $\mathrm{NaMnMg}($ lit) catalyst [31] provides drastically improved conversions of $\mathrm{CH}_{4}$ and higher selectivities to $\mathrm{C}_{2}$ products in the OCM with $\mathrm{O}_{2}$. The $\mathrm{BaY}$ samples show highest yields observed in this study and the use of $\mathrm{N}_{2} \mathrm{O}$ increases the $\mathrm{C}_{2}$ selectivity, however, at lower conversion of $\mathrm{CH}_{4}$ making it difficult to distinguish whether this effect is due to secondary combustion of $\mathrm{C}_{2}$ products or due to catalyst improvement. Full conversion of the oxidizing agent is observed in each experiment listed in Tab. 6. BiYSm(lit), $\mathrm{BaY}($ lit), and $\mathrm{NaMnMg}$ catalysts increase in activity with time-on-stream whereas all other samples show a stable catalytic performance or deactivate. BaY catalysts are unstable in $\mathrm{N}_{2} \mathrm{O}$ suggesting that a high oxidative potential is required to maintain the catalytic activity similar to the observation of the low $\mathrm{C}_{2}$ selectivity over the reduced $\mathrm{NaMnMg}(\mathrm{CT})$ sample..

A very poor catalytic performance in terms of OCM is observed for the NaBaSrTi catalysts. Zero selectivity to $\mathrm{C}_{2}$ products is found in a broad range of reaction conditions, the low $\mathrm{C}_{2}$ selectivity of $\mathrm{NaBaSrTi}$ (lit) in $\mathrm{O}_{2}$ is overshadowed by a rapid activity loss. Regarding the poor perperformance of these catalysts in the present study, the high $\mathrm{C}_{2}$ yield reported [32], however, under slightly different reaction conditions, is difficult to comprehend. Instead, the high selectivities to $\mathrm{CO}_{2}$ observed are in full agreement with the expected product spectrum for a perovskite-type catalyst [46]

The preparation method appears to be highly important for this group of catalysts. BiYSm and $\mathrm{BaY}$ catalysts provide a lower conversion of $\mathrm{CH}_{4}$ when prepared via $\mathrm{CT}$, which is a result of the drastically lowered $\mathrm{C}_{2}$ selectivity as found for the $\mathrm{Li}_{2} \mathrm{O} / \mathrm{MgO}$ type catalysts. Similarly, the higher activity as a result of higher surface areas of CT samples is assumed to induce hot spots in the catalyst bed, which lower the $\mathrm{C}_{2}$ selectivity and also the catalyst stability. For NaBaSrTi this effect is most obvious and the amenity of the CT method over citric acid sol gel synthesis is clearly visible [29] when $C_{2}$ selectivity is no object.

\subsubsection{Perovskite reference samples}

Perovskite-type oxides is a class of catalysts covering excellent materials for total oxidation of hydrocarbons with high selectivity to $\mathrm{CO}_{2}$ [46]. In the present study selected samples showing a high $\mathrm{CH}_{4}$ combustion performance with $\mathrm{O}_{2}$ [29] were additionally tested in the reaction with $\mathrm{N}_{2} \mathrm{O}$. Although the lattice structure is not stable under the reaction conditions applied as shown for $\mathrm{SrLaFeCo}(\mathrm{CT})$ in the catalyst characterization section the catalysts tested show a very high and stable catalytic performance (Tab. 7) with a high selectivity to $\mathrm{CH}_{4}$ combustion. The full conversion of $\mathrm{O}_{2}$ and $\mathrm{N}_{2} \mathrm{O}$ is found even at the lower reaction temperature of $1023 \mathrm{~K}$ and higher GHSV of $32,000 \mathrm{~h}^{-1}$. Lower conversions of $\mathrm{CH}_{4}$ when using $\mathrm{N}_{2} \mathrm{O}$ are a result of higher selectivities to $\mathrm{CO}_{2}$ obtained over these catalysts.

Furthermore, it is very interesting to note that trace amounts of $\mathrm{C}_{2}$ products are detected when using this mild oxidizing agent. The amounts of $\mathrm{C}_{2}$ products are even higher at the initial period of reaction and decrease with time-on-stream in parallel to the degradation of the perovskite lattice. It suggests that the initial well ordered structure, which brings up $\mathrm{C}_{2}$ selectivities of up to $2 \%$, has a certain, however limited, potential for OCM catalysis.

Table 7. Catalytic performances of perovskite catalysts in the reactions of $\mathrm{CH}_{4}$ with $\mathrm{O}_{2}, \mathrm{CO}_{2}$, and $\mathrm{N}_{2} \mathrm{O}$, respectively, at $1073 \mathrm{~K}$ and GHSV 3,600 $\mathrm{h}^{-1}$

\begin{tabular}{lllll}
\hline Catalyst & Oxidizing agent & $X\left(\mathrm{CH}_{4}\right)(\%)$ & $S\left(\mathrm{C}_{2}\right)(\%)$ & $\mathrm{dx} / \mathrm{dt}\left(\% \mathrm{~h}^{-1}\right)$ \\
\hline SrLaMn$(\mathrm{CT})$ & $\mathrm{O}_{2}$ & 28,8 & 0,0 & $-0,01$ \\
& $\mathrm{~N}_{2} \mathrm{O}$ & 24,6 & 0.7 & \pm 0 \\
\multirow{2}{*}{ SrLaFeCo $(\mathrm{CT})$} & $\mathrm{O}_{2}$ & 30,7 & 0,0 & $-0,03$ \\
& $\mathrm{~N}_{2} \mathrm{O}$ & 24,3 & 0,1 & $-0,03$ \\
\hline
\end{tabular}




\subsection{Relationship between catalyst composition and their performance in OCM}

The comparison of oxidizing agents for the OCM over state-of-the-art catalysts indicates that $\mathrm{N}_{2} \mathrm{O}$ could contribute to the solution of the $\mathrm{C}_{2}$ selectivity problem. The total activities are lower when using $\mathrm{N}_{2} \mathrm{O}$ as the oxidizing agent, however, accompanied by higher selectivities to ethylene and ethane (Fig. 4). It is in agreement with the fact that $\mathrm{N}_{2} \mathrm{O}$ is a mild and less reactive oxidizing agent, whereas $\mathrm{O}_{2}$ is highly reactive and more rapidly reoxidizes the catalyst surface. The higher selectivities observed at the lower conversions when using $\mathrm{N}_{2} \mathrm{O}$, however, can also be explained by reaction kinetics. Decreasing $S / X$-trajectories are an indicator for a Wheeler type III reaction network of product formation and consecutive product degradation [47] as it is suggested for the OCM [17]. An increased microkinetic selectivity can only be determined at isoconversion, i.e., by variation of GHSV. Unfortunately, several catalysts turned out to be too reactive thus providing full conversion of $\mathrm{O}_{2}$ and $\mathrm{N}_{2} \mathrm{O}$ in the whole range of GHSVs adjusted (e.g., SrLa, $\mathrm{LaCa}, \mathrm{NdCa}$ ). $S / X$ data obtained in this regime is hard to compare. The statistical analysis of the entire dataset, however, reveals a remarkable improvement of the $\mathrm{C}_{2}$ selectivity. In the range of $\mathrm{CH}_{4}$ conversions between $25-35 \%$, which comprises roughly 120 experimental data points of the entire dataset and corresponds to the upper limit of $\mathrm{N}_{2} \mathrm{O}$ reactivity data, the increase of the average $\mathrm{C}_{2}$ selectivity is $+11.1 \%$. The superior $\mathrm{N}_{2} \mathrm{O}$ performance can be due to the fact that the formation of gas-phase methyl peroxo species is strongly suppressed in the absence of gas-phase $\mathrm{O}_{2}$. Such species are considered as precursors of gas-phase $\mathrm{CO}_{2}$ [22]. Additionally, it is concluded that the superior performance of $\mathrm{N}_{2} \mathrm{O}$ compared to $\mathrm{O}_{2}$ is due to the formation of different adsorbed oxygen species upon catalyst reoxidation as previously reported for selective oxidation of low alkanes with $\mathrm{N}_{2} \mathrm{O}$ and $\mathrm{O}_{2}$ [4,5,48]. Mono-atomic species are the only species formed from $\mathrm{N}_{2} \mathrm{O}$, while bi-atomic oxygen species originate additionally from $\mathrm{O}_{2}$. The former species selectively convert $\mathrm{CH}_{4}$ to $\mathrm{C}_{2} \mathrm{H}_{6}$, while the latter ones are responsible for non-selective reaction products $(\mathrm{CO}$ and $\mathrm{CO}_{2}$ ). As suggested previously [5] for the OCM reaction over $\mathrm{Na} / \mathrm{CaO}$, the relative ratio of bi-atomic to monoatomic adsorbed species is influenced by the concentration of anion vacancies, which are active sites for $\mathrm{O}_{2}$ adsorption. The higher the concentration of anion vacancies is, the lower is the ratio and the higher the $\mathrm{C}_{2}$-selectivity is achieved. Such vacancies are created upon doping of $\mathrm{CaO}$ with $\mathrm{Na}_{2} \mathrm{O}$ in the range of formation of solid solutions.

With regard to the CT method as an alternative approach for catalyst preparation it turns out that these catalysts in most cases are in parts drastically inferior to the samples prepared via the respective methods reported in literature. One reason could be the higher surface areas obtained, which increase the global reactivity to create hot spots in the catalyst bed and finally accelerate the combus

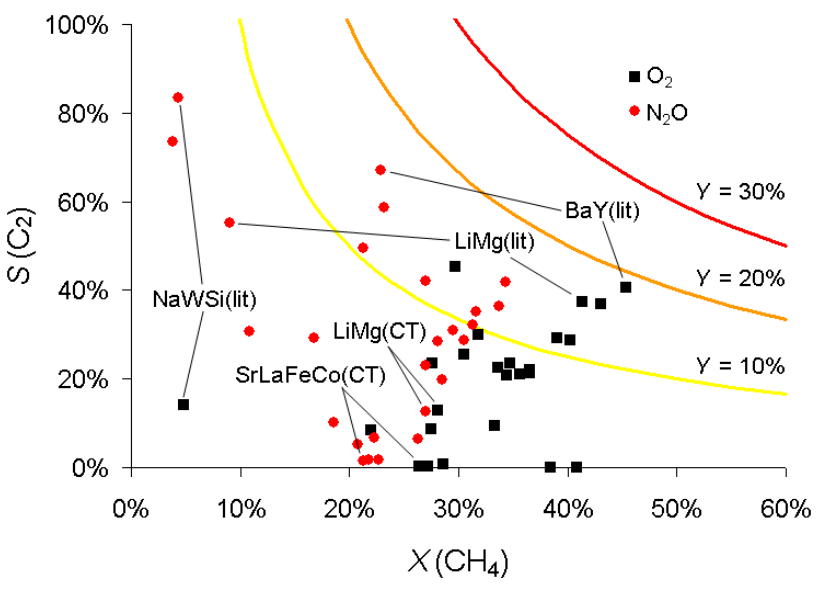

Figure 4. $S / X$-plot of catalytic performances obtained for all catalysts in the OCM with $\mathrm{O}_{2}$ and $\mathrm{N}_{2} \mathrm{O}$ at $1073 \mathrm{~K}$. The plot contains data representing the highest $\mathrm{C}_{2}$ yields obtained by variation of GHSV.

tion of $\mathrm{C}_{2}$ reactants and products. Another reason could be the phase composition and hierarchical structure, which is, e.g, not $\mathrm{BaF}_{2} / \mathrm{Y}_{2} \mathrm{O}_{3}$ in the $\mathrm{BaY}(\mathrm{CT})$ sample and not $\mathrm{Na}_{2} \mathrm{WO}_{4} / \mathrm{SiO}_{2}$ in the $\mathrm{NaWSi}(\mathrm{CT})$ sample. Instead, various highly dispersed bulk mixed oxide phases are formed from the homogeneous mixture of precursor ions used for cellulose impregnation, which apparently is detrimental to the catalytic performance.

The last point to be mentioned is that the recipes reported in literature not in each case produce a valuable OCM catalyst. Especially for $\mathrm{NaBaSrTi}(\mathrm{lit})$, which is reported to provide a $\mathrm{C}_{2}$ yield of almost $25 \%$ under reaction conditions similar to those applied in the present study [32], a poor catalytic performance with almost zero $\mathrm{C}_{2}$ selectivity is found, which agrees with the typically observed high total oxidation performance of perovskite type catalysts [46]. The best catalyst identified under similar reaction conditions are $\mathrm{BaY}(\mathrm{lit}), \mathrm{LiMg}(\mathrm{lit})$, and $\mathrm{LiMgCe}$ (lit) giving yields of $\mathrm{C}_{2}$ products close to $20 \%$. The fact that the industrially relevant range of $30 \%$ is not attained must be referred to non-optimized reaction conditions, i.e., molar composition of the feed. As can be seen from Tab. 1, the molar ratio of $\mathrm{CH}_{4}: \mathrm{O}_{2}$ often exceeds the stochiometric value of 2 , whereas the addition of an inert diluting agent is frequently omitted. Both factors could contribute to an improved catalytic performance.

\section{Conclusion}

The present study underlines that besides the chemical composition also the synthesis strategy is a crucial factor for success in terms of high $\mathrm{C}_{2}$ yields in the OCM reaction. Catalyst recipes and trends in catalytic performances reported in literature could be reproduced in most cases. High surface areas obtained with the cellulose templating method can favor non-selective consecutive oxidation of primarily formed ethane to carbon oxides. The 
contribution of the latter reaction can be reduced when using nitrous oxide compared to oxygen as the oxidizing agent. As a result higher $\mathrm{C}_{2}$ selectivities are achieved even at iso-conversion of methane. The superior performance of nitrous oxide is attributed to the nature of oxygen species formed upon catalyst reoxidation.

\section{Acknowledgements}

\section{References}

[1] G.E. Keller, M.M. Bhasin, J. Catal. 73 (1982) 9-19.

[2] J.C.W. Kuo, C.T. Kresge, R.E. Palermo, Catal. Today 4 (1989) 463-470.

[3] E.V. Kondratenko, O. Ovsitser, Angew. Chem. Int. Ed. 47 (2008) 3227-3229.

[4] U. Zavyalova, M. Geske, R. Horn, G. Weinberg, W. Frandsen, M. Schuster, R. Schlögl, ChemCatChem 3 (2011) 949-959.

[5] E.V. Kondratenko, O.V. Buyevskaya, M. Soick, M. Baerns, Catal. Lett. 3-4 (1999) 153-159.

[6] E.N. Voskresenskaya, L.I. Kurteeva, G.G. Pervyshina, A.G. Anshits, Catal. Today 24 (1995) 277-279.

[7] G.M. Pajonk, T. Manzalji, Appl. Catal. A 108 (1994) 41-51.

[8] H. Yamamoto, H.Y. Chu, M.T. Xu, C.L. Shi, J.H. Lunsford, J. Catal. 142 (1993) 325-336.

[9] K. Otsuka, T. Nakajima, J. Chem. Soc., Faraday Trans. I 83 (1987) 1315-1321.

[10] K. Aika, T. Nishiyama, J. Chem. Soc., Chem. Commun. (1988) $70-71$

[11] C. Chen, Y. Xu, G. Li, X. Guo, Catal. Lett. 42 (1996) 149153.

[12] S. Wang, Z.H. Zhu, Energy \& Fuels 18 (2004) 1126-1139.

[13] X. Li, K. Tomishige, K. Fujimoto, Catal. Lett. 36 (1996) 2124.

[14] N.X. Lu, G. Fu, X. Xu, H.L. Wan, J. Chem. Phys. 128 (2008) 034702

[15] T. Ito, J. Wang, C.H. Lin, J.H. Lunsford, J. Am. Chem. Soc. 107 (1985) 5062-5068.

[16] L.M. Aparicio, S.A. Rossini, D.G. Sanfilippo, J.E. Rekoske, A.A. Trevino, J.A. Dumesic, Ind. Eng. Chem. Res. 30 (1991) 2114-2123

[17] L. Mleczko, M. Baerns, Fuel Proc. Technol. 42 (1995) 217 248.

[18] S. Arndt, G. Laugel, S. Levchenko, R. Horn, M. Baerns, M. Scheffler, R. Schlögl, R. Schomäcker, Catal. Rev. - Sci. Eng. 53 (2011) 424-514

[19] S. Arndt, U. Simon, S. Heitz, A. Berthold, B. Beck, O. Görke, J.-D. Epping, T. Otremba, Y. Aksu, E. Irran, G. Laugel, M. Driess, H. Schubert, R. Schomäcker, Top. Catal. 54 (2011) 1266-1285

[20] Y. Kuo, F. Behrendt, M. Lerch, Z. Phys. Chem. 221 (2007) 1017-1037.

[21] P. Myrach, N. Nilius, S.V. Levchenko, A. Gonchar, T. Risse, K. Dinse, L.A. Boatner, W. Frandsen, R. Horn, H. Freund, R. Schlögl, M. Scheffler, ChemCatChem 2 (2010) 854-862.

[22] E.V. Kondratenko, M. Baerns, in:, G. Ertl, H. Knözinger, F. Schüth, J. Weitkamp (Eds.), Handbook of Heterogeneous Catalysis, Wiley VCH, 2008, pp. 3010-3023.

[23] A. Palermo, J.P. Holgado Vázquez, R.M. Lambert, Catal. Lett. 68 (2000) 191-196.
Financial support by the Deutsche Forschungsgemeinschaft (EXC 314) is gratefully acknowledged. The authors thank E. Kitzelmann, G. Lorentz, W. Frandsen, and G. Weinberg (FHI Berlin) for assistance on experiments.
[24] Y. Zeng, F.T. Akin, Y.S. Lin, Appl. Catal. A 213 (2001) $33-$ 45.

[25] H.R. Godini, H. Arellano-Garcia, M. Omidkhah, R. Karimzadeh, G. Wozny, Ind. Eng. Chem. Res. 49 (2010) 3544-3552.

[26] Y. Zeng, Y.S. Lin, S.L. Swartz, J. Membr. Sci. 150 (1998) 87-98.

[27] Y.I. Pyatnitskii, A.I. Bostan, L.N. Raevskaya, S.A. Nedil'ko, A.G. Dzyaz'ko, E.G. Zen'kovich, Theor. Exp. Chem. 41 (2005) 117-121.

[28] K. Langfeld, E.V. Kondratenko, O. Görke, R. Schomäcker, Catal. Lett. 141 (2011) 772-778.

[29] K. Langfeld, R. Marschner, B. Frank, R. Schomäcker, ChemCatChem 3 (2011) 1354-1358.

[30] C.T. Au, X.P. Zhou, Y.W. Liu, W.J. Ji, C.F. Ng, J. Catal. 174 (1998) 153-163.

[31] J.A. Sofranko, J.J. Leonard, C.A. Jones, A.M. Gaffney, H.P. Withers, Catal. Today 3 (1988) 127-135.

[32] Z. Fakhroueian, F. Farzaneh, N. Afrookhteh, Fuel 87 (2008) 2512-2516.

[33] H. Mimoun, A. Robine, S. Bonnaudet, C.J. Cameron, Appl. Catal. 58 (1990) 269-280.

[34] V.H. Rane, S.T. Chaudhari, V.R. Choudhary, J. Chem. Technol. Biotechnol. 81 (2006) 208-215.

[35] R.L.P. Gonçalves, F.C. Muniz, F.B. Passos, M. Schmal, Catal. Lett. 135 (2010) 26-32.

[36] F.T. Akin, Y.S. Lin, Catal. Lett. 78 (2002) 239-242.

[37] K. Langfeld, PhD thesis (submitted), Technical University of Berlin.

[38] A.N. Shigapov, G.W. Graham, R.W. McCabe, H.K. Plummer Jr, Appl. Catal. A 210 (2001) 287-300.

[39] P. Scherrer, Gött. Nachr. 2 (1918) 98-100.

[40] Note that this is only a rough estimate as the Scherrer equation is valid only for crystallite diameters below $100 \mathrm{~nm}$.

[41] Inorganic Crystal Structure Database, URL: http://icsd.fkf.mpg.de/ (Oct 2011).

[42] A. Mastalir, B. Frank, A. Szizybalski, H. Soerijanto, A Deshpande, M. Niederberger, R. Schomäcker, R. Schlögl, T. Ressler, J. Catal. 230 (2005) 464-475.

[43] S. Arndt, Stability of lithium doped magnesium oxide and zinc oxide catalysts for the conversion of natural gas, Technical University of Berlin, 2011.

[44] B. Frank, A. Dinse, O. Ovsitser, E.V. Kondratenko, R. Schomäcker, Appl. Catal. A 323 (2007) 66-76.

[45] E.V. Kondratenko, V. Gölden, S. Sokolov, ChemCatChem 2 (2010) 633-635

[46] L.G. Tejuca, J.L.G. Fierro, Properties and applications of perovskite-type oxides, Marcel Dekker, New York, 1993.

[47] A. Wheeler, Adv. Catal. 3 (1951) 249-327.

[48] X. Rozanska, E.V. Kondratenko, J. Sauer, J. Catal. 256 (2008) 84-94. 